\title{
Innovation as a new organizational function: evidence and characterization from large industrial companies in Brazil
}

\author{
Raoni Barros Bagno ${ }^{\mathrm{a} *}$, Mario Sergio Salerno ${ }^{\mathrm{b}}$, Ana Valeria Carneiro Dias ${ }^{\mathrm{a}}$ \\ a Universidade Federal de Minas Gerais, Belo Horizonte, MG, Brasil \\ bUniversidade de São Paulo, São Paulo, SP, Brasil \\ *rbagno@dep.ufmg.br
}

\begin{abstract}
Although innovation has acquired increasing importance for companies, achieving regular innovation capability imposes huge challenges for managers. Recent studies analyzed the experience of some large companies in setting up a dedicated team with the specific mission of conducting innovation management activities. Based on this analysis, innovation has been pointed to as a distinct and emerging organizational function. In this context, the central question posed in this study arises: what are the characteristics of such a function? Case studies were conducted in fifteen large industrial companies in Brazil that, except for two control cases, have established dedicated teams for innovation management activities. The analysis revealed key characteristics of the Innovation Function (IF), divided into six perspectives: general purpose, origins, legitimacy and guidance, people, assignments and future perspectives. The characterization of $\mathrm{IF}$ adds new elements to existing knowledge about how companies can build and maintain regular and systemic innovation capability. Keywords

Innovation management. Organizational functions. Industrial companies. Systematic innovation.

How to cite this article: Bagno, R. B., Salerno, M. S., \& Dias, A. V. C. (2017). Innovation as a new organizational function: evidence and characterization from large industrial companies in Brazil. Production, 27, e20162073. http:// dx.doi.org/10.1590/0103-6513.207316
\end{abstract}

\section{Introduction}

In the last decades, innovation has been gradually recognized as one of the main pillars of companies' competitiveness. In spite of this, the numerous contributions in the field of innovation management are fairly spread out. Sears \& Baba (2011) declare that literature on innovation subjects is characterized by its fragmentation, lack of transversality and little synthesis of the advances over the multiple levels of analysis. As stated by 0'Connor (2012), much of what has been studied represents small pieces of an organizational phenomenon that can raise richer insights if analyzed in a systemic perspective.

Innovation studies cover many areas of knowledge (Martin, 2012). In the management field, Burns \& Stalker (1961) were the first to relate innovation capability to different forms of organization. Later, studies on organizational ambidexterity expanded this discussion in many perspectives (e.g., 0'Reilly \& Tushman, 2004; Raisch et al., 2009) without, however, converging on clear paths through which organizations would become more innovative, and in a regular way. Also, the management of innovation is complex, exhibits strong interdisciplinary characteristics, and pervades several functional activities (Baregheh et al., 2009; McDermott \& 0'Connor, 2002). Thus, the adoption of traditional formulas like high investments in R\&D or even the best practices of markedly innovative organizations cannot provide reliable solutions (Hansen \& Birkinshaw, 2007; Jaruzelski et al., 2005). 
The literature has several recommendations on how to conduct innovation efforts in the organizations; however, typically, these initiatives do not hold up over time and such efforts are often decelerated or even canceled by short-term emergencies (Kelley, 2009). 0'Connor et al. (2008) attest that even organizations that feature emblematic cases of innovation projects may do so in an infrequent, irregular and unpredictable way. Such prospects reinforce the need to broaden a debate on the establishment of a systemic model, that can be integrated into the routine activities of the companies and assume innovation as a central mission, not dependent on special budgets or on the will of specific people (Skarzynski \& Gibson, 2008; 0'Connor et al., 2008).

Researchers at Rensselaer Polytechnic Institute (RPI) conducted a longitudinal study in 12 large corporations, all them immersed in the effort of systematizing innovation (Corbett et al., 2014; Kelley, 2009; 0'Connor \& DeMartino, 2006; 0'Connor et al., 2008). These authors conclude that innovation has evolved over a period of time to become a new organizational function in those companies - the Innovation Function (IF). For them, an organizational function is defined by the existence of a recognized and identifiable team that holds - and is measured by - a specific mission pertaining to that organization.

Taking the context of large industrial companies in Brazil engaged in systematizing innovation, this work aimed at seeking evidence of this phenomenon and answering the question: how can Innovation Function be characterized? The paper is organized as follows: theoretical basis comprises central concepts of innovation management, followed by a discussion on systematic innovation and Innovation Function. The next section presents multiple case studies as the methodological approach. The findings are divided into six perspectives, proposing a detailed characterization for IF. Subsequently, the synthesis of the results is presented in tabular form, followed by a theoretical discussion. Finally, the main constraints of the study and the implications for innovation management are presented.

\section{Literature review}

For the purposes of this study, innovation is defined as the exploration of new ideas successfully (United Kingdom, 2003). In the context of industrial organizations, this comprises new technologies or technological applications, better products and services, new production processes or even more efficient and cleaner processes and new business models.

The understanding of innovation as a process shapes the way in which companies experience and manage it (Tidd et al., 2009). Some classic innovation process models are largely considered in the literature and practice of innovation management - e.g. Stage Gates (Cooper, 1993), innovation funnel (Clark \& Wheelwright, 1992) or Open Innovation model (Chesbrough, 2003). O'Connor et al. (2008) propose the DNA model to deal specifically with the challenge of organizing and managing radical innovation. The model consists of three macro phases: Discovery, iNcubation (to isolate the discoveries from daily pressures until they gain enough potential) and Acceleration (when the discovery acquires the status of a new business) - each one associated with a specific capability to be built into the organization. The DNA is established under a set of organizational elements, necessary for a sustainable innovation management: (i) mandate and responsibilities; (ii) structure and processes; (iii) resources and skills; (iv) leadership and governance; and (v) metrics and rewards.

The fields that contributed to innovation studies throughout the last decades are many, which confirms the current diversity of perspectives around the theme. Martin (2012) identified the key intellectual developments in the innovation field over 50 years and concluded that the origins point to a range of disciplines in the late 1950s and 1960s. Among the sub-fields proposed by Martin (2012) to organize the scope of innovation studies, two are central to the present discussion: "management" (which includes R\&D management, new product development, technology and innovation management, entrepreneurship, knowledge management, and parts of strategic management) and "organizational studies" (which includes organizational innovation, a large part of the resource-based view of the firm - core competences, dynamic capabilities, absorptive capacity - and some contributions on organizational learning). Discussions about the innovation process go back to the seminal studies on New Product Development (as noted by Salerno et al., 2015; Silva et al., 2014). Whilst the notion of innovation capabilities to be leveraged in the organization that will ultimately influence the ideas of systematic innovation and Innovation Function have their origins in the fundamental concepts of Dynamic Capabilities (e.g. Teece \& Pisano, 1994), which, in turn, builds upon the theoretical foundations provided by Resource Based View of the Firm (e.g. Barney, 1986; Penrose, 1959).

Certainly, the approach of innovation as a process to be managed in companies is central. However, to some extent, innovation management literature has become over-biased in a process-centric view, loosely considering the underlying (but no less important) activities and other managerial elements that enable the main process to work (0'Connor, 2012; Salerno et al., 2015; Tidd et al., 2009). In this sense, an effective innovation management 
demands a better understanding of the organizational structures and managerial behaviors that best fit the business contingencies (Salerno et al., 2015; Tidd et al., 2009).

In addition to the adoption of a management process, O'Connor et al. (2008) state that a company aimed at innovating regularly, must design a system. According to Skarzynski \& Gibson (2008, p. 246-247):

[...] if would-be innovators can only succeed in an organization despite the system - if they have to fight their way heroically through a minefield to push their ideas forward - then by definition, innovation is not a systemic capability in that organization, nor is it a core value that is deeply ingrained in the corporate culture.

Tao et al. (2010) argue for the need of business management approaches that support the innovation process. However, Skarzynski \& Gibson (2008) note that, in most organizations, innovation is forced to disconnect from the rest of the company and often assume the form of isolated departments of R\&D or NPD, Skunk Works, or specific divisions for new businesses.

0'Connor et al. (2008) argue that someone or a group should be responsible for innovation in established companies. The authors justify such a proposition on the following grounds: (i) organizational capability building is not simple, especially when confronted with operational efficiency-oriented processes; (ii) the accumulation of experiences demands consistency and continuity of the people involved; (iii) the existence of a group responsible for the occurrence of innovation motivates the whole company to reflect on the real progress of these activities and the possible reconfigurations necessary to improve them and; (iv) it is necessary to develop appropriate skills to innovate radically.

0'Connor (2012) defines "organizational function" as the existence of an identifiable team that has the responsibility to lead a specific mission of the company. The author points out that, a few decades ago, companies did not have marketing departments, nor was such a function well defined in organizations. However, marketing has become a sophisticated function, incorporating different processes to meet different mandates. As an implication, innovation function (IF) should have its own leadership, metrics, vocabulary, career paths and permanent power in organizations.

Creating a dedicated team to focus on innovation is a growing phenomenon in global organizations that invest in organic growth opportunities, instead of acquiring companies or investing in start-ups (Swisher, 2012). Börjesson et al. (2014) described how two automotive firms developed capabilities for innovation, focusing on the efforts of dedicated teams in managing an innovation portfolio and building capabilities for innovation. In turn Labitzke et al. (2014) studied German hospitals and found a positive relation between innovation activity and the existence of a dedicated IF. Keupp et al. (2012) consider the internal organization a very powerful lever to bring about innovatory outcomes, which, reversely, evoke a continuing need for organizational adaptation.

0'Connor et al. (2008) argue that a group of people aimed at consolidating innovation as a permanent function of the organization should have these main tasks: to stimulate the generation of ideas; involve senior leadership in clarifying the strategy; seed funded projects; support innovation project teams; scan the external environment to capture trends; invest in small businesses; interact with other organizational functions; help to develop governance over innovation efforts, support decision-making and facilitate portfolio reviews and; monitor innovation capability. According to Tolbert \& Zucker (1999), the establishment of a new function, to a greater or lesser degree, necessarily causes changes in other functions, as changes in parts of an organization require adaptive changes in others. The tensions between an innovation team and the main operations of a company are identified by Govindarajan \& Trimble (2010) as a major threat for innovation efforts. Therefore, minimizing these tensions requires special attention to three points: a) the correct division of work; b) constitution of a team dedicated to innovation - what determines new working relationships and; c) conflict mitigation, in which the legitimization of innovation efforts through direct senior management support plays a special role. Gibson (2010) argues that innovation must be "institutionalized" in organizations and compares this challenge to the efforts previously undertaken by companies in the Total Quality Management (TQM) approach.

\section{Methodology}

This work aims at seeking evidence of IF emergence in large-sized industrial companies in Brazil and also at characterizing such a function. To start thinking about an adequate methodological approach to achieve these objectives the "evidence problem" directly influences the unit of analysis and requisites of a non-random sample of companies. The characterization problem guides the design of instruments for collecting data and the forms to categorize data to support the analysis. Also, "characterization" may be better clarified if deployed in some sub-questions: why the selected companies considered establishing a dedicated function for innovation 
and which events induce such a decision? What is IF's central mission in these companies? What are its typical roles and resources? In which managerial levels of the organization IF operates? What would be the similarities and/or de-similarities with other functions, like production or R\&D?

The methodological strategy adopted in the research was the multiple case studies, for which the use of an appropriate sample is necessary to avoid strange variations in the object of analysis (Eisenhardt, 1989). This also helps to define the boundaries of generalization of the results. So, two fundamental criteria were considered for case selection: (i) the existence of an identifiable group of people with the central responsibility to conduct innovation efforts (which confirms that the company has the IF at some level of maturation and open paths to explore the "evidence" problem) and; (ii) the adequacy in terms of the selected context of research (large industrial companies). The study applies inductive logic (Eisenhardt \& Graebner, 2007) and theory building comes from (a) the common categorization of data collected in each case (enabling adequate comparisons) and; (b) identification of convergences/ divergences/ complementarities among cases.

The case-selection was made based on the experience of authors with some companies in previous studies and also on the suggestions collected from partners such as innovation management consulting firms, government instances related to innovation public policies and economic development and the Brazilian Association for Research and Development of Innovative Companies (ANPEl). This first effort resulted in about 25 companies to be prioritized for a first invitation to collaborate in the research. Some of the companies present in the first list did not respond to the invitation and others were cut because they did not meet research requisites. A few others were added at the suggestion of the managers of the firms contacted. Finally, the study was conducted with 15 companies: 13 of them strictly met the basic requirement of having identifiable IF. However, two exceptions were intentionally included in the sample (companies Chem-2 and Transp-4), as detailed below. Table 1 shows the companies studied, location of each headquarters and some information about their general contexts. The companies were given fictitious names that make reference to their sectors of activity: Telec (equipment, software and services for IT and telecommunications), Chem (companies based on chemical production processes), Transp (development and assembly of equipment, products and sub-systems for transport applications), Elect (development and assembly of electrical and electronic equipment), Min (extraction) and Metal (metallurgy/steel). Table 2 presents the central missions addressed to the innovation team of each company and also informs the respondents' positions in the organizational structure.

As mentioned above, Chem-2 and Transp-4 did not have an identifiable IF, but they were included in the sample to provide richer insights and comparisons. Chem-2 is very renowned in national and international arenas for its systematized practices of innovation, although had no singular team to assign specific responsibility for innovation efforts. Transp-4, at the time of the field study, was still on the verge of establishing a formalized innovation team. Such a context made it especially propitious to investigate the antecedents of IF and the proper efforts on taking the decision of implementing $\mathrm{IF}$ and starting the organization of the team.

Although Metal-1 met the basic requirements, this case was also considered special since it is the only case in which a strong retrogression of IF occurred despite having in the past a high level of dedicated structure and respective formalization. In a previous study, about 2.5 years before, the innovation team was at the apex and a large number of initiatives was ongoing. There were many people dedicated to the activities related to innovation management, which had a high strategic importance. However, an economic crisis abruptly interrupted the efforts.

As stated, this study follows the definition of 0'Connor et al. (2008) for organizational function - the existence of a recognized and identifiable team that holds and is measured by a specific mission pertaining to that organization. However, this statement does not offer enough elements to allow a characterization as proposed in this study. Although the organizational functions are as old as the organizations themselves, Aveiro \& Tribolet (2006) note that the term is poorly defined in the literature. Thus, the challenge of characterizing a new function required us to identify elements that could help to collect and organize data, since a precise framework of what constitutes an organizational function was not available as expected. These elements were then identified and selected by concatenating the perspective of 0'Connor et al. (2008) with works from other strands such as Aveiro \& Tribolet (2006), Tolbert \& Zucker (1999), Ein-Dor \& Segev (1982) and Meyer \& Rowan (1977). Based on this analysis, twelve elements were identified as important to characterize an organizational function and were articulated among the questions of the interview protocol: (a) the mission or output of the innovation team; (b) activities undertaken to achieve the mission; (c) organizational form (department, transverse program, etc.); (d) budget allocation; (e) mechanisms to control and evaluate functional performance; (f) leadership and its coordination mechanisms; (g) people involved in the function and their profile; (h) career paths; (i) skills and competencies required to perform the function; (j) relations with other functions in the organization; ( $k$ ) the forms by which function's role is communicated to the rest of the organization; (l) formal and informal links established with agents of the external environments. 
Table 1. Companies studied and their general context.

\begin{tabular}{|c|c|}
\hline Comps. & Context \\
\hline $\begin{array}{c}\text { Chem-1 } \\
\text { Brazil }\end{array}$ & $\begin{array}{l}\text { Chem- } 1 \text { results from many alliances and acquisitions. It starts as a fast follower of commoditized products, but sectoral regulation } \\
\text { forced investments in R\&D. Chem-1 is a base industry with rigid continuous production processes and there are innovation } \\
\text { opportunities in new applications of its products. Innovation management is conducted in a formalized department with clear } \\
\text { objectives, budget and stable links with the rest of the organization. }\end{array}$ \\
\hline $\begin{array}{l}\text { Chem-2 } \\
\text { Overseas }\end{array}$ & $\begin{array}{l}\text { Company globally recognized for its innovation. Chem- } 2 \text { dominates technologies that can be combined in different ways, opening } \\
\text { opportunities to innovate. Innovation in chem- } 2 \text { has been consolidated over many decades and there is no centralized team to } \\
\text { manage it. }\end{array}$ \\
\hline $\begin{array}{c}\text { Chem-3 } \\
\text { Brazil }\end{array}$ & $\begin{array}{l}\text { A spin-off from a big industrial group, based on commodities and a strongly regulated market. Innovation management in the } \\
\text { previous company was well institutionalized. Innovation team responds to the technological center, with the central mission of } \\
\text { bringing regulatory, normative, knowledge management, IP and prospection issues to the debate. }\end{array}$ \\
\hline $\begin{array}{c}\text { Chem-4 } \\
\text { Brazil }\end{array}$ & $\begin{array}{l}\text { Brazilian company, very recognized by a distinct market/distribution model, based on people networks. Innovation is a common value } \\
\text { and processes are well consolidated. The vice-presidency of innovation takes several specific responsibilities with regard to culture, } \\
\text { competences, academic programs, open innovation efforts, etc. }\end{array}$ \\
\hline $\begin{array}{l}\text { Elect-1 } \\
\text { Overseas }\end{array}$ & $\begin{array}{l}\text { A global industrial conglomerate, with many business units (BUs), each one based on specific technology and market. Innovation } \\
\text { efforts in BUs are mainly incremental. Radical innovation is conducted at the corporate level by the innovation board, that } \\
\text { concatenates external partnerships with the demands/interests of the BUs. }\end{array}$ \\
\hline $\begin{array}{l}\text { Elect-2 } \\
\text { Brazil }\end{array}$ & $\begin{array}{l}\text { A group with some BUs that supply electric-based systems for the operation of industrial plants and associated services. Customized } \\
\text { products were a good strategy to conquer market share, but currently rethinking volume-variety strategy is necessary to establish as a } \\
\text { large-sized organization. An innovation program conducts R\&D activities, captures funding and seeks out academic partnerships. }\end{array}$ \\
\hline $\begin{array}{l}\text { Elect-3 } \\
\text { Overseas }\end{array}$ & $\begin{array}{l}\text { This company operates on B2C market with strong brands of products. Technology and design play important roles in firm's } \\
\text { innovation. Different configurations of Innovation teams marked the last decade, but, finally, a "stable" team had a proper space } \\
\text { inside the New Product and Innovation Development Department, mainly after a significant market grew in the late 2000's. }\end{array}$ \\
\hline $\begin{array}{c}\text { Elect-4 } \\
\text { Brazil }\end{array}$ & $\begin{array}{l}\text { Brazilian company with global recognition for quality and innovation, that supplies subsystems of Elect-3's products. Captive } \\
\text { market is responsible for much of the revenues, but there are notably opportunities for innovation in other markets. The long-term } \\
\text { partnership with a local university marks the innovation path. Innovation activities were very fragmented before the innovation team } \\
\text { was formally created in } 2010 \text {. }\end{array}$ \\
\hline $\begin{array}{c}\text { Metal-1 } \\
\text { Brazil }\end{array}$ & $\begin{array}{l}\text { After decades of technological learning from foreign sources, Metal- } 1 \text { became monopolist in many markets, also favored by the } \\
\text { global economic context in 2000's. A well-structured technology center was in place for many years, and this scenario funded } \\
\text { the creation of a big innovation department, assigned to manage the technological center and also other transverse initiatives of } \\
\text { innovation culture, communication, knowledge management, etc. In spite of this, a period of strong contentions directly affected the } \\
\text { organizational structure associated with innovation. Metal- } 1 \text { is an example of strong retrogression of innovation efforts, despite a } \\
\text { previous phase of high formalization and power of innovation structures. }\end{array}$ \\
\hline $\begin{array}{c}\text { Min-1 } \\
\text { Brazil }\end{array}$ & $\begin{array}{l}\text { A rich and giant commodity company with operations spread over several sites. Although this facilitates access to resources and } \\
\text { government support, the organizational structure is notably heavy and imposes special challenges for innovation management. } \\
\text { Innovation is focused on processes and distribution operations. }\end{array}$ \\
\hline $\begin{array}{c}\text { Telec-1 } \\
\text { Brazil }\end{array}$ & $\begin{array}{l}\text { Telec- } 1 \text { competes in a very dynamic market in which stability represents a risk. Innovation is focused on new products for B2B context } \\
\text { in a highly regulated environment, which reduces the importance of marketing competences. Public procurement represents good } \\
\text { opportunities to propel the business. An innovation program was created to make the innovation process more regular and fluent. }\end{array}$ \\
\hline $\begin{array}{c}\text { Transp-1 } \\
\text { Brazil }\end{array}$ & $\begin{array}{l}\text { A Brazilian company that has a well-consolidated technological competence. The business is centered on a highly complex product } \\
\text { for the B2B market. The so called innovation team born more recently and has focused on innovation efforts such as culture, } \\
\text { management tools, new business development. }\end{array}$ \\
\hline $\begin{array}{l}\text { Transp-2 } \\
\text { Overseas }\end{array}$ & $\begin{array}{l}\text { Transp-2 represents an industrial sector dominated by subsidiaries of global companies, but very prominent in Brazil of 2000's, } \\
\text { after an important period of consolidation of capabilities in new product development (NPD). Success in this industry had been } \\
\text { marked by the practices of operational excellence, which turns into a barrier to introduce a culture of innovation. The technological } \\
\text { development is still very dependent on knowledge of the foreign units. }\end{array}$ \\
\hline $\begin{array}{c}\text { Transp-3 } \\
\text { Overseas }\end{array}$ & $\begin{array}{l}\text { Transp- } 3 \text { was responsible for one of the main Transp-2's product subsystems and belonged to the same industrial group. An } \\
\text { innovation program was set up in } 2008 \text {, but, at the time of data collection for this study, was on the verge of establishing a } \\
\text { dedicated department. }\end{array}$ \\
\hline $\begin{array}{l}\text { Transp-4 } \\
\text { Overseas }\end{array}$ & $\begin{array}{l}\text { Transp-4 competes with Transp-2, but its Brazilian subsidiary is significantly younger. Recent sectoral regulations (which stimulated } \\
\text { the siting of local R\&D and production activities, partnerships with universities, etc.) was a strong lever for innovation efforts. } \\
\text { Transp- } 4 \text { was on the verge of the creation of an innovation program at the time of data collection. Spread initiatives marked the } \\
\text { innovation efforts in previous periods. }\end{array}$ \\
\hline
\end{tabular}

After conducting all the interviews, a pre-analysis led to six categories to group the data: (i) general purpose of IF; (ii) origins (context of function creation); (iii) legitimacy (the level in which IF is acknowledged for its role and the perimeter of action); (iv) people (leadership, team profile and careers); (v) assignments (core mission and the underlying tasks that are seen as the function's intrinsic responsibilities and part of its expertise); and (vi) future projections (medium and long term). Categories (i), (iii), (iv) and (v) come from the combination of the twelve elements identified in the literature. Categories (ii) and (vi) synthesize the variables of the internal and external environments related to the context in which the function arises and evolves.

After categorization and data reduction, conceptual frames were built for each company, which combined primary (interviews) and secondary data. Then, these frames were returned to each company to be adjusted and/or validated. At this stage information was checked by individuals other than the first respondents, but also 
Table 2. Cases studied.

\begin{tabular}{|c|c|c|}
\hline Company & Person Interviewed & Innovation team's core mission \\
\hline Chem-1 & Corporate Innovation Director & $\begin{array}{l}\text { - Standardization of innovation practices throughout the organization. } \\
\text { - ldea generation, and development until bench tests. } \\
\text { - Agglutination of managerial competences related to innovation. }\end{array}$ \\
\hline Chem-2 & $\begin{array}{l}\text { Innovation Manager-industrial } \\
\text { market }\end{array}$ & Develop innovative products, and new business opportunities. \\
\hline Chem-3 & $\begin{array}{l}\text { Resource Coordinator for } \\
\text { systems and technology }\end{array}$ & $\begin{array}{l}\text { - Relieve researchers from "administrative burden" in technological innovation projects (avoid } \\
\text { "noise" in technical activities). } \\
\text { - Synergistic competence gains in supporting activities that are vital for research efficiency. }\end{array}$ \\
\hline Chem-4 & $\begin{array}{l}\text { Manager of networks and } \\
\text { partnerships for innovation }\end{array}$ & $\begin{array}{l}\text { Governance of the innovation process, network building for S\&T, product development, and issues } \\
\text { related to consumer safety. }\end{array}$ \\
\hline Elect-1 & $\begin{array}{l}\text { Director of technology and } \\
\text { innovation }\end{array}$ & $\begin{array}{l}\text { - Underlying activities related to innovation in a more synergic way in order to generate value for } \\
\text { several BU's. } \\
\text { - Serve as formal input channel for opportunities that come from external partners and/or require } \\
\text { special skills, spread in the company. }\end{array}$ \\
\hline Elect-2 & Manager of innovation core & Formulation and acceleration of business plans, attraction of funds and partners for R\&D. \\
\hline Elect-3 & $\begin{array}{l}\text { Innovation area } \\
\text { (several respondents) }\end{array}$ & $\begin{array}{l}\text { - Ensure sustainability and financial returns from innovation. } \\
\text { - Define a local innovation strategy; } \\
\text { - Manage the innovation process, defining and managing targets for other teams involved in } \\
\text { innovation initiatives; } \\
\text { - Catalyze the engagement of people in innovation activities; } \\
\text { - Generate, lead, and manage innovation projects. }\end{array}$ \\
\hline Elect-4 & $\begin{array}{l}\text { Institutional Relations Manager- } \\
\text { R\&D/ Innovation }\end{array}$ & Conduct the technological plan and monitor the innovation funnel. \\
\hline Metal-1 & $\begin{array}{l}\text { Innovation team - board of } \\
\text { directors }\end{array}$ & $\begin{array}{l}\text { "Orchestrate" innovation efforts regarding products and processes, and to integrate these efforts } \\
\text { into the routine of other company sectors. }\end{array}$ \\
\hline Min-1 & Innovation Manager & $\begin{array}{l}\text { Promote adequate environment for technological innovation through science-oriented activities, } \\
\text { open innovation partnerships and funding for strategic projects. }\end{array}$ \\
\hline Telec-1 & $\begin{array}{l}\text { Manager of innovation } \\
\text { Committee }\end{array}$ & $\begin{array}{l}\text { Systematization and organization of processes associated with radical innovation (daily routine } \\
\text { processes would just deal with incremental innovations). }\end{array}$ \\
\hline Transp-1 & $\begin{array}{l}\text { Manager of Innovation and } \\
\text { knowledge management }\end{array}$ & $\begin{array}{l}\text { - "Take care" of innovation within the company, by promoting corporate policies, processes, } \\
\text { organizational environment and knowledge management. } \\
\text { - Create metrics for innovation. }\end{array}$ \\
\hline Transp-2 & $\begin{array}{l}\text { Manager of strategic planning } \\
\text { and Innovation }\end{array}$ & $\begin{array}{l}\text { Systematize innovation, balancing operational efficiency efforts. } \\
\text { The innovation team should encourage innovation in the company, but was not responsible for } \\
\text { idea generation. }\end{array}$ \\
\hline Transp-3 & Innovation Program Manager & $\begin{array}{l}\text { Capture opportunities concerning new products, partnership consolidation with universities and } \\
\text { public funding. }\end{array}$ \\
\hline Transp-4 & $\begin{array}{l}\text { Research and Development } \\
\text { Manager -innovation }\end{array}$ & $\begin{array}{l}\text { Get closer to universities and leverage opportunities related to new products, markets and } \\
\text { processes. Part of the team also focused on opportunities regarding information technology, } \\
\text { innovation culture and partnership consolidation. }\end{array}$ \\
\hline
\end{tabular}

directly involved in IF. This was done in order to check for errors relating to the interpretation of data, personal biases and to fill some data gaps. After these steps, information was considered definitive for final analysis and the elaboration of conclusions.

\section{Findings}

This section presents the main conclusions and analyzes of the cases studied in the research. The subtopics are organized according to the categories presented in the methodology and present the main observed convergences.

\subsection{Innovation function's general purposes}

Essentially, a company's innovation does not happen inside IF proper domains, neither is IF the company's place where "innovators" meet. Normally, IF assumes the role of an innovation catalyst or facilitator among the other instances in the organization. To do so, IF assumes responsibilities that are not attributable to other processes and/or existing functions, and manages horizontal connections to integrate complementary skills, necessary for the success of innovation efforts. The more innovative (to the company) are the projects and their underlying activities, the more respondent IF is expected to be in order to fill the gaps.

In this context, IF-R\&D connections deserve special discussion. The cases reveal that IF and R\&D function can live together in three different ways: (i) IF may be under R\&D if it is part of an R, D\&E-like structure and performs direct support to this instance. This form was prominently observed in Chem-3, Elect-3, Elect-4, Transp-2 
and the last configuration of Transp-3; (ii) IF may be over R\&D when it contains R\&D, nurturing decisions on the portfolio and resources. This form was observed in Chem-1, where IF was created to promote businesses' "de-commoditization" and in Metal-1, where the technology center responded to the Innovation Directory; (iii) IF and R\&D may operate in parallel with one another. IF is focused on doing actions for innovation culture, new business development, organizational changes, etc. This form was observed in Telec-1, Transp-1, Chem-4, Elect-1, Elect-2, Min-1 and was in the initial form of Transp-3. The configuration of IF has an impact on its relationships with other organizational functions. Thus, when IF is part of the R\&D, its main relationships are with the project teams; conversely, when IF contains R\&D, its assignments are broader as well as its interfaces with organizational functions other than R\&D such as Human Resources, Sales, Marketing etc. In the third configuration, IF also has interfaces with other organizational functions, but these relationships tend to be weaker and less influential than in the second configuration.

\subsection{Origins of innovation function}

Below are the most cited reasons for creating such a function. Normally, a case in particular cannot be explained by just one reason, but by a combination of them.

- Previous innovation initiatives and/or projects. In Chem-1, a new product with a special environmental appeal leveraged the competition in a new market with greater added value than the commodities so far offered by the company. Transp-3 had just developed an innovative product with new features before the decision that led to the creation of IF. For its part, Telec-1 developed a high-tech product for the public sector, but has failed due to misalignments with end customers' expectations. In many cases, the success of projects (despite the poor environment) or even failures (attributable to the lack of a good environment) motivated reflections that seeded IF. In other cases, spread innovation efforts preceded IF creation. E.g.: Chem-3 (belonged to a bigger corporation that already hold IF), Chem-4 (efforts from small and not connected groups preceded IF) and Elect-4 (IF had been evolving for over 10 years, but subordinated from one area to another).

- Political-economic context and technological environment. This point is given by the potential of the local market, public policy, local funding and C\&T infrastructure. Elect-1 experienced an increasing demand for capital goods, whereas Elect-4 identified opportunities in a niche of more sophisticated products. Chem-1 institutionalized IF after a normative requirement regarding mandatory investments in technological innovation. Other companies like Elect- 1 and Transp-4 identified opportunities in markets linked to the priorities of the Brazilian industrial policy. Chem-4, Transp-2 and Transp-4 have focused on the competences of local universities to justify IF creation.

- Market defense. In Chem-1 and Chem-3, commoditization was the main threat when companies decided for IF creation. Metal-1 had been threatened even in markets previously considered captive. In dynamic sectors, the avoidance of obsolescence proved to be a trigger, as observed in Transp- 1 and Telec-3, both threatened by the local marketing of competitors' products already disseminated abroad.

- Business diversification. For Transp-1, which already had well consolidated structures for R\&D and NPD, this was the main trigger for IF creation. Elect- 1 and Elect- 2 bet on IF to catalyze opportunities that could result in entirely new business units.

- Establishment of a brand associated to innovation. IF can motivate important institutional relationships. This may expose the company to new markets and relieve some social pressures. In Chem-4, Min-1, Transp-2, Transp-3 and Transp-4, having an image of innovative company was associated with several new business opportunities and the attraction of new partners.

- Follower reaction. Seeing other companies involved in innovation efforts could also influence the decision for creating an IF. Consulting firms also help to propagate this "need".

Most companies were still shaping IF in its structural form and operation, changing the strategic focus and/or processes. The average time of $\mathrm{IF}$ creation was five years and ten of the companies have been leading such efforts for five years or less.

\subsection{Innovation function legitimacy and guidance}

The discussion about the legitimization of a phenomenon still considered embryonic is very challenging and requires a longer period of investigation. However, the following points raise potential issues linked to $\mathrm{IF}$ legitimization. 
- Short-term results. By assumption, IF should be aimed at long-term goals. However, some short-term outcome can help minimize internal attacks. The demand for some "quick" projects was crucial in Transp-3 for the maintenance of the innovation team and marked the use of suggestion systems in Min-1.

- External links. Project partners and financing agencies can bring an "outer anchorage" for IF in so far as they involve the company's image in the external environment. In Elect-2, such partnerships were commonly done before an internal "sale" of innovation opportunities in order to associate the idea with a greater backing. In Chem-1, Telec-1 and Elect-2, the involvement of corporate clients aimed both at raising support for the IF and at reducing the market uncertainty for new projects.

- Clear assignments. The cases highlighted the importance of establishing clear missions and assignments for IF (associated with the whole strategic plan and recognized throughout the organization), instead of open scopes. In Min-1, projects not aligned with strategic priorities caused constant relocations and little support for IF in the organization. In Chem-1 a clear role in the company's strategy was crucial to IF's stability.

- Organizational configuration. When IF is directly associated with the strategic levels its legitimacy may be more easily achieved.

- Regulatory demands. In some industries, regulatory pressure for innovation is a relevant element to support IF within the organization. The most prominent examples are Chem-1, Elect-1, Transp-2 and Transp-4.

- Internal communication. Several cases revealed efforts in diffusing IF's initiatives and achievements via newsletters, events, etc. In addition, when IF works together with other organizational functions, it immediately communicates its mission and achievements, therefore the way IF is inserted within the organizational architecture also matters.

Another issue is the legitimacy of IF in the context of transnational companies. In this sense, IF may be a locus and a product of the struggle for legitimacy of the subsidiary within global corporations. Indeed, innovation activities are often a way of achieving technological upgrading that guarantees resources and even long term survival (Hobday \& Rush, 2007). Therefore, setting up innovation activities in a subsidiary is not only an assignment made by the headquarters but also a product of the local strategy (Bouquet \& Birkinshaw, 2008). In this case a structured IF empowers the subsidiary in the decision of where to locate R\&D globally.

\subsection{People and organizational design}

Normally, few people work in the core of IF (less than 10, in almost all cases observed). This core team is the most responsible for carrying out $\mathrm{IF}$ assignments. Nevertheless, three other organizational instances complement the function (Figure 1): (i) strategic committees (formulate guidelines for IF), (ii) focal points (people formally allocated in other parts of the organization that work as local extensions of IF and facilitate horizontal communication), and (iii) project teams (temporary structures to conduct innovation projects).

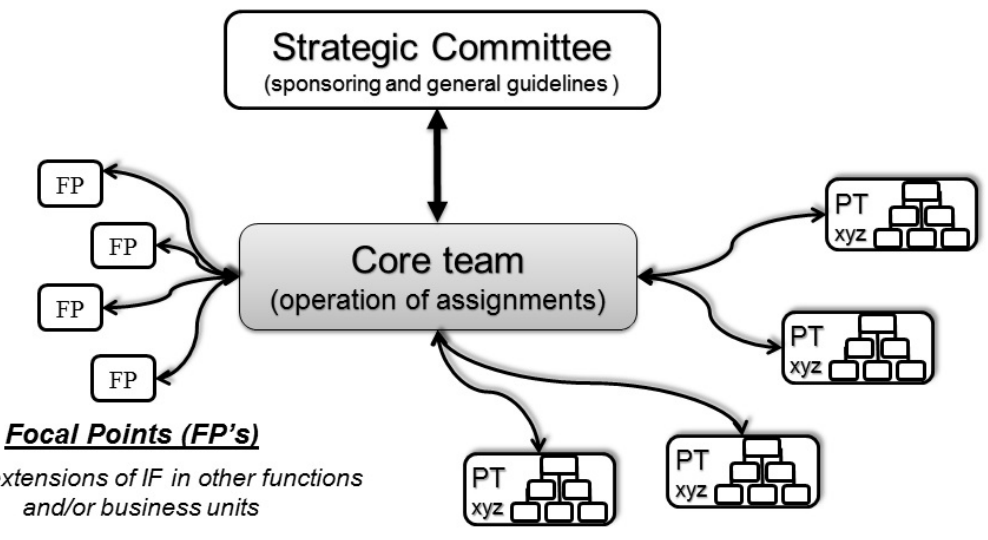

Project Teams (PT's)

Conduction of portfolio active projects

Figure 1. Organizational instances associated with Innovation Function. 
Engineering specialties, Design, Business and Management and Economics are the most common degrees among people who work in the core team of the IF. However, diversified previous experiences, creativity, initiative, propensity to take risks, among others, are equally or more valued than formal education. This was very clear in Transp-1 and Elect-1.

From the perspective of talent attraction, four main elements were observed: (a) the possibility of a good career in IF; (b) the personal affinity with innovation; (c) escape, when IF appears as an option for (and is receptive to) people with blocked careers; and (d) initial career leverage, when working in IF promotes exposure to other areas due to intense horizontal interaction.

\subsection{Assignments of innovation function}

The assignments are probably the strongest elements to characterize an organizational function, since they are directly related to the function's specialties. Twelve assignments were identified for IF along the cases studied and are presented below.

- Raising funds and getting tax incentives: search for resources, calls, project elaboration (or translation) to dispute calls of funding agencies, getting tax benefits, among other tasks.

- Establishment of partnerships with Science and Technology Institutes (STIs). Leverage and manage partnerships with universities, public or private, local or foreign and/or other kinds of research centers.

- Other partnerships. Partnerships with industry associations, clients, suppliers, government, etc. It is considered a particular assignment because establishing these partnerships often involves different skills, language and objectives from those with STls.

- Management of innovation portfolio and projects. Portfolio management can be done at several levels: (i) control, balance and the establishment of metrics; (ii) new project planning and initial scope/resource definition (partners, project team, project-specific metrics, etc.); (iii) management support (and maybe execution) of innovation projects from the start to diffusion.

- Management of intellectual property (IP). Outlining of IP policies, patent management, patent mining, analysis of other forms of knowledge protection, licensing, support on contract elaboration of partnerships, etc.

- R\&D. As mentioned, R\&D can be a direct assignment of IF or, on the other extreme, R\&D can hold IF as its support function, usually for methodological purposes.

- Strategic, technological or market prospection. Studies of future scenarios to support the innovation strategy, project selection and/or resource planning. This is usually associated with the application of specific managerial approaches such as Roadmapping or Business Intelligence.

- Dissemination of innovation culture. Actions for promoting a work environment conducive to innovation: events, communication, people involvement channels, etc.

- Competence building. Actions aimed at increasing capabilities in innovation management and technological skills that could enable future strategies (e.g., academic programs).

- Idea management. Employees' suggestions systems (in their many possible configurations) and/or intrapreneurship programs.

- Knowledge management. It hosts activities such as use of communities of practice; blogs for discussions on innovation topics; dissemination efforts of tacit knowledge; diffusion of trainings and events; etc.

- Leverage of new businesses and incursions in venture capital. These include inorganic ways to compete through innovation such as new business development and spin-off; acceleration of startups; etc.

It should be noted that no case showed the internalization of all assignments nor was the same level of importance observed among the assignments. Furthermore, assignments seemed to emerge over time to the extent that IF consolidates in organizational environment and get its borders and scope clearer.

\subsection{Future perspectives for innovation function}

In all the interviews, the respondents were asked to share their future prospects for IF. There were some points of agreement among these views, which are described below. 
IF can strengthen the focus on diffusing innovation culture all around the company, expanding the traditional product/process innovation perspective. Elect-3, Min-1 and Transp-3 are examples of teams that have started their activities with a more prominent approach in acculturation for innovation, but then turned back to a greater technological bias. Chem-2 is an example of innovation culture fully entrenched in the routine of the entire company.

The cases show no sign that the IF core team should become significantly larger (e.g. turning it into a big department), maybe because it does not tend to accumulate new tasks in so far as the innovation is catalyzed in the company. Nevertheless, the activities carried out in IF tend to be nobler. In some cases, it is stated that the IF should gradually abandon methods and/or tasks that come to be systematized in other areas by turning its attention just in picking up new trends. However, this view is balanced by another that fears the loss of synergy and a possibility of reverting to the "old" ways of dealing with innovation. Regarding the establishment of partnerships, public universities were still the central concern to open innovation. However, cases like Transp-1, Chem-2 and Transp-2 are examples of more structured actions to suppliers' involvement in innovation efforts whereas Elect- 1 is prominent in networking with various agents other than universities. More diversified opportunities and less bureaucratic barriers are some points that motivate this tendency.

Lastly, rather than only deploying the company's strategy, IF can gradually turn into a key agent of the strategy. Also, IF increasingly builds competence in dealing with high risk/uncertainty projects. A definition of IF that summarizes the various perspectives collected about the future is: small boards with high influence in strategic thinking and a great interaction with other areas in regard to the innovation dynamics of the whole company.

\section{Discussion}

Table 3 summarizes the main topics discussed in section 4 in which the columns represent the perspectives - or the factors - used to characterize IF. Despite the descriptive side of the results, the study models - and, by assumption, theorizes, since it offers some predictive value (Boer et al., 2015) - an organizational phenomenon observable in companies that seek regular and systematic innovation. To recover the expression used by Schmenner, "discovery is prelude to theory" (Boer et al., 2015, p. 1238). Since seeking evidence of IF is a form to validate important facts, it is as important as theorizing on IF. Furthermore, IF is a social phenomenon and so, a good analysis must consider an adequate balance between comprehensiveness and parsimony (Whetten, 1989). This was a requisite to define the factors needed to judge about the evidence of such a phenomenon and to exploit it.

The field showed that not all the characteristics could be simultaneously observed in the cases, nor could the factors selected to make such a characterization be considered exhaustive, which reinforces the use of inductive logic to analyze data - although this kind of logic imposes some limits on the generalization that sums with temporal and contextual constraints of data collected (Whetten, 1989). Notwithstanding, the characteristics and descriptions provided were enough to consider IF a particular instance being formed in those organizations and that it presents its own particularities. The assignments are, no doubt, the strongest characteristic that distinguishes IF from other functions, since they are helpful to describe Fl's specialties. Other characteristics increase the understanding of how IF arises, what environmental conditions were in place, how IF gets installed in an organization and which were the implications for people, processes and structures. Thus, the characteristics identified and the way they relate to each other contribute to achieve internal and external coherence for the construct. However, IF is an embryonic phenomenon and, if description inspires prescription, interventions based on these findings require some caution.

With regard to people, the reasons that lead one to have a desk in IF are many and it is expected that these reasons affect IF's performance and legitimation in a longer period. In general, it emphasizes the importance of designing the function and career paths associated with it, rather than just counting on resources made available in the organization and/or achieving diversity. Gottschalg \& Zollo (2007) attest that motivation (extrinsic, normative intrinsic, and hedonic intrinsic) can be an enabler of the potentials of an organization and acts as a complement to resource- and competence-based approaches. According to Theriou \& Chatzoglou (2008), specific Human Resource Management practices are vital to the increase of people motivation and compromise, which are critical factors to leverage rare and valuable resources. Moreover, O'Connor et al. (2008) point to the lack of a clear career path as one of the reasons talent is so rare for IF. Not just the skills necessary for innovation differ from those required to run an ongoing operation, but also Innovation experts within a company are called to act as change agents.

According to Keupp et al. (2012), problems in implementation of innovation efforts are a pivotal cause for the inability of managers to achieve the intended benefits of the innovations in many organizations. Moreover, 
Table 3. Synthesis of the results: the characteristics of Innovation Function.

\begin{tabular}{|c|c|c|c|c|}
\hline Purpose and Origins & Legitimacy and Guidance & $\begin{array}{c}\text { People and Organizational } \\
\text { Design }\end{array}$ & Assignments & Future Perspectives \\
\hline $\begin{array}{l}\text { IF acts as an lnnovation } \\
\text { catalyzer - not executor }\end{array}$ & $\begin{array}{l}\text { Some short term result } \\
\text { is vital }\end{array}$ & $\begin{array}{l}\text { IF can be depicted in a core } \\
\text { team, strategic committees, } \\
\text { focal points and project } \\
\text { teams }\end{array}$ & \multirow{4}{*}{$\begin{array}{l}\text { IF presents twelve different } \\
\text { assignments: } \\
\text { - Capture of funding and } \\
\text { tax incentives } \\
\text { - Establishment of } \\
\text { partnerships with STls } \\
\text { - Other partnerships } \\
\text { (industry associations, } \\
\text { clients, suppliers, } \\
\text { government, etc.) } \\
\text { - Management of } \\
\text { innovation portfolio and } \\
\text { projects } \\
\text { - Management of IP } \\
\text { - R\&D } \\
\text { - Strategic, technological } \\
\text { or market prospection } \\
\text { - Dissemination of } \\
\text { innovation culture } \\
\text { - Competence building } \\
\text { - ldea management } \\
\text { - Knowledge management } \\
\text { - Leverage of new } \\
\text { businesses and incursions } \\
\text { in venture capital }\end{array}$} & $\begin{array}{l}\text { Increase the focus on } \\
\text { diffusing the culture of } \\
\text { innovation throughout the } \\
\text { company }\end{array}$ \\
\hline $\begin{array}{l}\text { IF is embryonic and is } \\
\text { being constantly adjusted } \\
\text { within organizations }\end{array}$ & $\begin{array}{l}\text { Strategical role must be } \\
\text { clear }\end{array}$ & $\begin{array}{l}\text { Few people work } \\
\text { permanently in IF's core } \\
\text { team }\end{array}$ & & $\begin{array}{l}\text { Constitution of more } \\
\text { complex innovation } \\
\text { networks }\end{array}$ \\
\hline $\begin{array}{l}\text { The more "new to the } \\
\text { company" is an innovation } \\
\text { opportunity, more } \\
\text { responsive IF is expected } \\
\text { to be }\end{array}$ & $\begin{array}{l}\text { Network relationships } \\
\text { generate supports from the } \\
\text { outside }\end{array}$ & $\begin{array}{l}\text { Many educational } \\
\text { backgrounds mark } 1 \mathrm{~F} \\
\text { people: engineering, } \\
\text { management, economics } \\
\text { and design, but social skills } \\
\text { count more }\end{array}$ & & $\begin{array}{l}\text { Nobler activities, but with } \\
\text { no bigger scopes }\end{array}$ \\
\hline $\begin{array}{l}\text { IF is not R\&D, but the } \\
\text { IF-R\&D interactions has an } \\
\text { impact on IF's relationships } \\
\text { with other functions }\end{array}$ & $\begin{array}{l}\text { Regulatory concerns help } \\
\text { to support IF }\end{array}$ & $\begin{array}{l}\text { People come to IF seeking } \\
\text { for new career options, } \\
\text { personal affinity, escape } \\
\text { strategy (blocked careers) } \\
\text { or exposure }\end{array}$ & & \multirow[t]{2}{*}{$\begin{array}{l}\text { Small, but highly influential } \\
\text { boards, with great } \\
\text { interaction with other areas }\end{array}$} \\
\hline $\begin{array}{l}\text { Previous initiatives, } \\
\text { economic incentives, S\&T } \\
\text { environment, market } \\
\text { struggles, brand image and } \\
\text { follower reaction are the } \\
\text { main triggers of IF }\end{array}$ & $\begin{array}{l}\text { Proximity to strategic levels } \\
\text { and good communication } \\
\text { of initiatives and } \\
\text { achievements diffuse IF } \\
\text { throughout organization }\end{array}$ & $\begin{array}{l}\text { Clearer strategies for talent } \\
\text { attraction are needed }\end{array}$ & $\begin{array}{l}\text { There is no case with } \\
\text { all assignments neither } \\
\text { with the same level of } \\
\text { importance among them. } \\
\text { Assignments may arise } \\
\text { over time }\end{array}$ & \\
\hline
\end{tabular}

these authors state that organizational design has received little attention in literature and that there is a lack of empirical evidence. By analyzing how $\mathrm{IF}$ arose and gained its contours in some organizational contexts, this study nurtures initial efforts of IF implementations. As O'Connor (2012) suggests, when seeking for sharper theoretical contributions on particular aspects of innovation management in organizations, researchers often overlook opportunities that stem from seeing the phenomenon from a more systemic level. The perspective of organizational function captures insights and commonalities about this level of reality, even in the presence of significant sectorial diversity, which contributes to the theory and opens new paths for research.

Finally, the recognition of the limits associated with the functional structure of organizations a few decades ago apparently puts the "process" as the most important element to explain how the company works and by which the company could be improved. However, bringing back the concept of organizational function to the discussion is not a return to the rigidness of the old functional structures, but a recognition that complex and uncertain missions may require the agglutination of distinct knowledge in new disciplines, and/or the gap filling among current disciplines to generate new outputs in such a way that the traditional organization functions cannot support even in the presence of well-designed processes.

\section{Conclusion}

This work intends to seek evidence of the Innovation Function in large-sized industrial companies in Brazil and, also the characterizing of such a function. After analyzing multiple cases in large industrial firms, the identified characteristics of IF were organized into six perspectives, viz., (i) general purposes; (ii) origins; (iii) legitimacy; (iv) people; (v) assignments and (vi) future perspectives. It is important to consider that, to some extent, particular characteristics of the Brazilian industrial environment act as shapers of the organizational forms studied. So, generalizations and convergences for other contexts must be discussed with care. Furthermore, the emergence and consolidation of a new organizational function is certainly a dynamic phenomenon. It depends on a larger set of external and internal variables.

As stated, the general purpose of $\mathrm{IF}$ is to catalyze the occurrence of innovations in the organizations. To do this, this function comprises a set of specialties to interact with the rest of the organization. However, it is necessary to note that the constitution of an organizational function dedicated to innovation cannot be 
asserted as the only way by which companies seek systematic innovation as reinforced by the case of Chem- 2 . Moreover, the creation of a formal department to deal with innovation is not a sufficient shield against the internal attacks in organizations. Metal-1 illustrates how a moment of crisis or changes in strategic vision can cause the retraction of efforts. Nevertheless, this study highlights that the constitution of IF is an important and empirically sustained alternative to integrate efforts to systematize innovation in organizations.

In respect to innovation management theory, the study helps to consolidate IF as a new unit of analysis, providing a framework for newer studies to deepen the understanding of IF assignments and/or its characteristics. Transversal investigations among IF, ambidexterity and/or other strands could also open new and richer paths for research.

\section{References}

Aveiro, D., \& Tribolet, J. (2006). An ontology for organizational functions: the recursive self-maintenance mechanism of the enterprise. In Proceedings of the 10th IEEE International Enterprise Distributed Object Computing Conference Workshops (EDOCW'06), Hong Kong, China.

Baregheh, A., Rowley, J., \& Sambrook, S. (2009). Towards a multidisciplinary definition of innovation. Management Decision, 47(8), 1323-1339. http://dx.doi.org/10.1108/00251740910984578.

Barney, J. B. (1986). Strategic factor markets: expectations, luck, and business strategy. Management Science, 32(10), 1231-1241. http:// dx.doi.org/10.1287/mnsc.32.10.1231.

Boer, H., Holweg, M., Kilduff, M., Pagell, M., Schmenner, R., \& Voss, C. (2015). Making a meaningful contribution to theory. International Journal of Operations \& Production Management, 35(9), 1231-1252. http://dx.doi.org/10.1108/1JOPM-03-2015-0119.

Börjesson, S., Elmquist, M., \& Hooge, S. (2014). The challenges of innovation capability building: learning from longitudinal studies of innovation efforts at Renault and Volvo Cars. Journal of Engineering and Technology Management, 31, 120-140. http://dx.doi. org/10.1016/j.jengtecman.2013.11.005.

Bouquet, C., \& Birkinshaw, J. (2008). Weight versus voice: how foreign subsidiaries gain attention from corporate headquarters. Academy of Management Journal, 51(3), 577-601. http://dx.doi.org/10.5465/AMJ.2008.32626039.

Burns, T. E., \& Stalker, G. M. (1961). The management of innovation. London: Tavistock Publishing House.

Chesbrough, H. (2003). Open innovation: the new imperative for creating and profiting from technology. Harvard: Harvard Business School Press.

Clark, K. B., \& Wheelwright, S. C. (1992). Revolutionizing Product Development: quantum leaps in speed, efficiency, and quality (1st ed.). New York: The Free Press.

Cooper, R. G. (1993). Winning at new products: accelerating the process from idea to launch. Reading: Addison-Wesley Publishing.

Corbett, A. C., O'Connor, G. C., \& Peters, L. (2014). Designing the organization for corporate entrepreneurship and institutionalizing the Innovation Function (interactive paper). Frontiers of Entrepreneurship Research, 34(16), 19.

Ein-Dor, P., \& Segev, E. (1982). Information systems: emergence of a new organizational function. Information \& Management, 5(4), 279-286. http://dx.doi.org/10.1016/0378-7206(82)90008-8.

Eisenhardt, K. M. (1989). Building theories from case-study research. Academy of Management Review, 14(4), 532-550.

Eisenhardt, K. M., \& Graebner, M. E. (2007). Theory building from cases: opportunities and challenges. Academy of Management Journal, 5O(1), 25-32. http://dx.doi.org/10.5465/AMJ.2007.24160888.

Gibson, R. (2010). Excelência em inovação: lições das campeãs brasileiras. Harvard Business Review, 85(2), 129-138.

Gottschalg, 0., \& Zollo, M. (2007). Interest alignment and competitive advantage. Academy of Management Review, 32(2), $418-437$. http://dx.doi.org/10.5465/AMR.2007.24351356.

Govindarajan, V., \& Trimble, C. (2010). Stop the innovation wars. Harvard Business Review, 6, 77-83.

Hansen, M. T., \& Birkinshaw, J. (2007). The innovation value chain. Harvard Business Review, 85(6), 121-130, 142. PMid:17580654.

Hobday, M., \& Rush, H. (2007). Upgrading the technological capabilities of foreign transnational subsidiaries in developing countries: the case of electronics in Thailand. Research Policy, 36(9), 1335-1356. http://dx.doi.org/10.1016/j.respol.2007.05.004.

Jaruzelski, B., Dehoff, D., \& Rakesh, B. (2005, November 29). Money Isn't Everything: lavish R\&D budgets don't guarantee performance. strategy+business.

Kelley, D. (2009). Adaptation and organizational connectedness in corporate radical innovation programs. Journal of Product Innovation Management, 26(5), 487-501. http://dx.doi.org/10.1111/j.1540-5885.2009.00676.x.

Keupp, M. M., Palmié, M., \& Gassmann, O. (2012). The strategic management of innovation: a systematic review and paths for future research. International Journal of Management Reviews, 14(4), 367-390. http://dx.doi.org/10.1111/j.1468-2370.2011.00321.x.

Labitzke, G., Svoboda, S., \& Schultz, C. (2014). The role of dedicated innovation functions for innovation process control and performance: an empirical study among hospitals. Creativity and Innovation Management, 23(3), 235-251. http://dx.doi.org/10.1111/caim.12068.

Martin, B. R. (2012). The evolution of science policy and innovation studies. Research Policy, 41(7), 1219-1239. http://dx.doi.org/10.1016/j. respol.2012.03.012.

McDermott, C. M., \& O'Connor, G. C. (2002). Managing radical innovation: an overview of emergent strategy issues. Journal of Product Innovation Management, 19(6), 424-438. http://dx.doi.org/10.1016/S0737-6782(02)00174-1.

Meyer, J. W., \& Rowan, B. (1977). Institutionalized organizations: Formal structure as myth and ceremony. American Journal of Sociology, 83(2), 340-363. http://dx.doi.org/10.1086/226550. 
O'Connor, G. C. (2012). Innovation: From Process to Function. Journal of Product Innovation Management, 29(3), 361-363. http:// dx.doi.org/10.1111/j.1540-5885.2012.00909.x.

0'Connor, G. C., \& DeMartino, R. (2006). Organizing for radical innovation: An exploratory study of the structural aspects of Rl management systems in large established firms. Journal of Product Innovation Management, 23(6), 475-497. http://dx.doi. org/10.1111/j.1540-5885.2006.00219.x.

0’Connor, G. C., Leifer, R., Paulson, A. S., \& Peters, L. S. (2008). Grabbing lightning: building a capability for breakthrough innovation. San Francisco: John Wiley \& Sons.

0’Reilly, C. A., \& Tushman, M. L. (2004). The ambidextrous organisation. Harvard Business Review, 82(4), 74-81. PMid:15077368.

Penrose, E. T. (1959). The theory of the growth of the firm. New York: Sharpe.

Raisch, S., Birkinshaw, J., Probst, G., \& Tushman, M. L. (2009). Organizational ambidexterity: Balancing exploitation and exploration for sustained performance. Organization Science, 20(4), 685-695. http://dx.doi.org/10.1287/orsc.1090.0428.

Salerno, M. S., Gomes, L. A. V., Silva, D. O., Bagno, R. B., \& Freitas, S. L. T. U. (2015). Innovation processes: Which process for which project? Technovation, 35(1), 59-70. http://dx.doi.org/10.1016/j.technovation.2014.07.012.

Sears, G. J., \& Baba, V. V. (2011). Toward a multistage, multilevel theory of innovation. Canadian Journal of Administrative SciencesRevue Canadienne Des Sciences, 28(4), 357-372. http://dx.doi.org/10.1002/cjas.198.

Silva, D. O., Bagno, R. B., \& Salerno, M. S. (2014). Models for innovation management: review and analysis of the literature. Production, 24(2), 477-490.

Skarzynski, P., \& Gibson, R. (2008). Innovation to the core. Boston: Harvard Business School Press.

Swisher, P. (2012). The case for establishing an innovation function. Global View, 1(3), 1-4.

Tao, L., Probert, D., \& Phaal, R. (2010). Towards an integrated framework for managing the process of innovation. $R$ \& D Management, 4O(1), 19-30. http://dx.doi.org/10.1111/j.1467-9310.2009.00575.x.

Teece, D., \& Pisano, G. (1994). The dynamic capabilities of firms: an introduction. Industrial and Corporate Change, 3(3), 537-556. http://dx.doi.org/10.1093/icc/3.3.537-a.

Theriou, G. N., \& Chatzoglou, P. D. (2008). Enhancing performance through best HRM practices, organizational learning and knowledge management: a conceptual framework. European Business Review, 20(3), 185-207. http://dx.doi.org/10.1108/09555340810871400.

Tidd, J., Pavitt, K., \& Bessant, J. (2009). Managing innovation: integrating technological, market and organizational change (4th ed.). John Wiley \& Sons.

Tolbert, P. S., \& Zucker, L. G. (1999). The institutionalization of institutional theory (pp. 169-184). London: SAGE.

United Kingdom, Department for Business, Energy \& Industrial Strategy - DT1. (2003). Innovation report: competing in the global economy: the innovation challenge. Retrieved in 15 February 2016, from http://webarchive.nationalarchives.gov.uk/+/http://www. berr.gov.uk/files/file12093.pdf

Whetten, D. A. (1989). What constitutes a theoretical contribution? Academy of Management Review, 14(4), 490-495. http://dx.doi. $\operatorname{org} / 10.2307 / 258554$

Received: Feb. 15, 2016

Accepted: Mar. 24, 2017 